\title{
Exploring the relationship between immigrant enclave theory and transnational diaspora entrepreneurial opportunity formation
}

Osa Godwin Osaghae Dr

Technological University Dublin, osa.godwin.osaghae@tudublin.ie

Thomas M. Cooney

Technological University Dublin, thomas.cooney@tudublin.ie

Follow this and additional works at: https://arrow.tudublin.ie/buschmarart

Part of the Business Administration, Management, and Operations Commons, Entrepreneurial and Small Business Operations Commons, and the Marketing Commons

\section{Recommended Citation}

Osa-Godwin Osaghae \& Thomas M. Cooney (2020) Exploring the relationship between immigrant enclave theory and transnational diaspora entrepreneurial opportunity formation, Journal of Ethnic and Migration Studies, 46:10, 2086-2105, DOI: 10.1080/1369183X.2018.1560001

This Article is brought to you for free and open access by the School of Marketing at ARROW@TU Dublin. It has been accepted for inclusion in Articles by an authorized administrator of ARROW@TU Dublin. For more information, please contact arrow.admin@tudublin.ie, aisling.coyne@tudublin.ie,gerard.connolly@tudublin.ie.

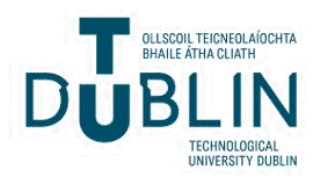




\title{
Understanding How Immigrant Entrepreneurs
}

\section{View Business Opportunity Formation Through Ethnicity}

\author{
Kingsley Njoku and Thomas M. Cooney
}

\section{Introduction}

In recent years, numerous research studies internationally have recognized the contribution of immigrant entrepreneurship to national economic growth. One constant element in many of these research findings has been a higher-than-average rate of immigrant self-employment, even while the direction and demographic composition of migrations might have changed fundamentally within a country (Ram, et al., 2017). Blanding (2016) suggested that one-quarter of entrepreneurs in the United States are immigrants, while Burn-Callendar (2016) highlighted that immigrants in the United Kingdom (UK) are three times more likely to be entrepreneurial than natives, with 15.4 percent of immigrant adults launching companies compared to just 5.3 percent of lifelong UK residents. Indeed, an OECD (2011) study of all OECD countries found that the percentage of immigrant entrepreneurs starting a business is higher than for natives (12.6 percent versus 12.0 percent), although the survival rate of immigrant-owned businesses is lower than the figure for new businesses started by native-born entrepreneurs. The study also found that an immigrant entrepreneur who owns a small or medium firm creates between 1.4 and 2.1 additional jobs, slightly less than their native-born counterparts (1.8 - 2.8). If immigrants are starting businesses at a faster rate than native entrepreneurs, then it would be beneficial to examine how immigrant entrepreneurs view business opportunity formation through ethnicity as the understanding of this relationship is currently underdeveloped.

For many years now, the term 'immigrant entrepreneurship' has been employed to indicate a specific category of entrepreneurship relating to persons who are immigrants and have started a business in their host country (Peterson, 1980). Early research on the topic recognised that immigrant entrepreneurs shared migration experiences or common national backgrounds, plus they identified with each other through a pattern of interactions strictly known to them (Waldinger et al., 1990). More recently, immigrant entrepreneurship has been explored from a wide variety of perspectives, with studies highlighting that immigrant entrepreneurs share distinctive experiences and challenges that the majority population do not endure (Rahman et al, 2018). Furthermore, it has also been determined that immigrants have a limited knowledge of the host country market, they suffer racial discrimination which impacts upon their business and they have difficulty in establishing trust with the local population (Cooney and Flynn, 2008). What is less understood is how these challenges influence entrepreneurial opportunity formation amongst immigrant entrepreneurs.

Some research studies have sought to explain how mixed embeddedness has contributed to the growth of immigrant businesses and their sustainability in their host countries (Rahman et al, 2018). 
Indeed, several such studies have stressed that the concept of mixed embeddedness describes the important nature of interactions that take place between the social, economic and institutional contexts. These contexts offer some distinguishing differences between an immigrant's entrepreneurial business opportunity creation process model and the approach taken by native entrepreneurs (Kloosterman et al., 1999). Given that business opportunities consist of an entrepreneur's actions, evaluations and reactions to the market and its context, they are habitually treated as a nonlinear and recursive process (Dimov, 2007; Alvarez and Barney, 2007). Therefore, a framework for understanding mixed embeddedness has been described as a theoretical lens that can be utilised for studying the phenomenon of an immigrant entrepreneurship business opportunity formation process model. Within this approach, research has indicated that the immigrant business opportunity creation process will begin with an entrepreneurial idea (Dimov, 2007; Davidsson, 2003) which is considered the primary starting point for any entrepreneurship process or new venture development (Evansluong, 2016). Therefore, the present complexity of the actions and interactions between immigrant entrepreneurs and the context (Johannisson, 2011; Steyaert, 2007) requires additional research to understand insights into immigrant mixed embeddedness perspectives and the nature of all functions, activities and actions related to their opportunity perceptions, and the formation of organizations to pursue these opportunities (Bygrave, 2004).

Moroz and Hindle (2012) proposed that two important characteristics of an immigrant entrepreneurship formation process model are duration and multiplicity. Bergson (1983) suggested that the length and continuity of actions and reactions that occur both in the past and present represent 'duration', while 'multiplicity' is used to describe the interactions between individuals and different actors within a given context. More recently, Lasselle and McElwee (2016) developed an illustrative representation of the concept of opportunity structures for ethnic minority entrepreneurs that incorporated the different demand and supply side dimensions influencing entrepreneurial activity, while Zhou and Liu (2017) contended that immigrant entrepreneurship has served as a key pattern of adaptation among new Chinese migrants and that this long-standing pattern is shaped by different migration histories, structural circumstances in both sending and receiving societies, and locations in the transnational social fields. However, Alexandre-Leclair (2014) concluded that further research needs to be undertaken on the links between age, gender, and culture to complete the current studies on diversity and entrepreneurship, a topic that remains underdeveloped.

To gain a greater understanding of business opportunity formation for immigrant entrepreneurs, this chapter will explore the role of ethnicity through the lens of mixed embeddedness theory. Based on a literature review, a framework will be presented based on multiple interactive components. Furthermore, the chapter will contribute to existing knowledge in three ways:

1. It further expands on prior conceptual studies regarding the contributions and roles played by immigrant entrepreneurs; 
2. Using a visual relational diagram, it explains how ethnicity relates to business opportunity formation through constant interactions;

3. It introduces the Visual Mixed Embeddedness Framework (VMEF) as an empirical lens for understanding the differences in the business opportunity formation process models between immigrant and native entrepreneurs.

While the chapter will explore immigrant entrepreneurship from a mixed embeddedness perspective to determine how differently it influences immigrant entrepreneurial activities to comparable native entrepreneurs, the primary goal is to develop a framework that will visually and accurately represent how the immigrant entrepreneurship process model differs from the native model relative to business opportunity formation.

\section{Three Different Dimensional Approaches to Ethnicity and Entrepreneurship}

Academic literature relating to immigrant entrepreneurship and ethnicity has widely acknowledged that the notion of 'ethnicity' not only provides immigrant entrepreneurs with valuable resources, but also with 'ideological support' for mercantile association in restraint of trade (Light and Rosenstein, 1995). Prashantham et al. (2015) and Valdez (2016) revealed that by bringing entrepreneurs together around an ideology of solidarity, family and ethnicity offers immigrant entrepreneurs a countervailing force used in defiance of market competition. Also, it has been argued that the nature by which opportunities are structured affect how immigrant groups access these opportunities. For instance, where market conditions favour only businesses serving the needs of an ethnic community, it reduces the availability of entrepreneurial opportunities (Cooney and Flynn, 2008). Aldrich and Waldinger (1990) examined ethnicity and entrepreneurship using a framework based on three dimensions: (1) an ethnic group's access to opportunity; (2) the characteristics of a group; and (3) emergent strategies. These dimensions are a useful structure through which one can explore the relationship between ethnicity and entrepreneurship.

To examine the first dimension for understanding ethnicity and entrepreneurship, it is important to question how available opportunities might be for immigrant ethnic minorities. Aldrich and Waldinger (1990) found that regardless of market conditions and the fact that business resources are controlled by non-ethnic group members, it is imperative that immigrant minorities have access to business opportunities to be efficient in the marketplace. Yeasmin (2016) ascertained that the presence of political factors can either impede or support the workings of different business markets, unwittingly making it more difficult or easier for potential immigrant entrepreneurs to have access to ownership positions. As an example, after the decline of mining in the late 1860s, Chinese immigrants encountered severe competition from 'White People' which denied them access to better-paying sectors (e.g. manufacturing, construction, etc), leaving them with the laundry businesses as the only option (Ong, 1981). In addition, Lieberson (1980) added that the impact of the competition was more severe on 
'Black People' (Africans) than it was on the Chinese. These examples highlight how the nature of hurdles faced by immigrant business minority groups, before they can access business opportunities in host countries, are frequently influenced by ethnicity.

On the second dimension to understanding ethnicity and entrepreneurship, studies by researchers such as Kusow et al. (2018) have argued that the socioeconomic achievements of immigrant groups are partly due to sociocultural orientation motives, ambitions acquired from group membership, and a function of an individual's human capital. Within this dimension, Aldrich and Waldinger (1990) noted that 'group characteristics' have two elements: predisposing factors and resource mobilization. While predisposing factors focused on skills and goals brought by individuals and groups, resource mobilization showed that every business requires capital and labour to run and function, and that immigrant entrepreneurs are no exception to these necessities. Furthermore, Light's (1984) model identified that cultural endowments, reactive solidarity and sojourning orientation are classified as ethnic resources because potential owners can use them during opportunity formation activities. Therefore, institutional completeness and internal solidarity give immigrant groups advantage to mobilize resources, with conditions historically contingent and heavily independent upon individual initiative, and subject to manipulation by dominant groups (Aldrich and Waldinger, 1990).

In the final dimension to understanding ethnicity and entrepreneurship, studies by Boissevain et al. (1990) and Ado et al. (2016) indicated that immigrant entrepreneurs create ethnic strategies by adapting to the resources available to them, interacting with opportunity structures, and by building on group characteristics. Immigrant entrepreneurial strategies are therefore observed in both their operational business opportunity structure and in the characteristics of group owners. As Waldinger et al. (1990a) conceptualized, the interaction between immigrant entrepreneurs and their business development model indicated that the business development and entrepreneurial success of an ethnic group cannot be traced back to a single characteristic. Instead, a group's success is dependent on a complex interaction that takes place between opportunity structure (i.e. market conditions, niche markets, open markets, access to ownership, job market condition and legal framework) and a group's resources (i.e. cultural traditions and ethnic social networks). Immigrant ventures are successful subject to the different roles played by the coming together of these components to create an environment which enables the implementation of opportunity formation process by members of this group. Hence, the presence of cultural diversities and traditions create significant market opportunities (e.g. the need to provide large goods and services) which immigrants handle strategically based on their requirements. As Volery (2007) highlighted, immigrant entrepreneurial success strategies to create viable opportunities in the host economies cannot be traced back to a single characteristic given its cyclical nature and level of interdependency.

A conceptualized model by Waldinger, Aldrich and Ward (1990) provides detailed explanations illustrating how the implementation of immigrant entrepreneurial success strategies is dependent on the interaction between opportunity structure and resources. Also, it has been argued that 
the entrepreneurship dimension exists independently of a potential entrepreneur's ethnic, cultural or religious background and that it influences the pursuit of entrepreneurial opportunities (Dana, 2007). Thus, an immigrant entrepreneurship model is influenced by additional factors beyond those faced by native entrepreneurs. Figure 1 below captures some of the factors that influence immigrant entrepreneurship through the recognition of two essential aspects, that the individual is from a different ethnic group, and that the individual in question is an entrepreneur (Volery, 2007).

\section{FIGURE 1 ABOUT HERE}

When examining immigrant businesses, the importance of entrepreneurial dimensions such as innovation and risk taking were also identified. Although, it has been argued that immigrant businesses are known for replicating and reproducing old forms rather than breaking new ground in product / service offerings (e.g. high percentage of immigrant businesses found in retail and service sectors), Dana (2007) maintained that every immigrant business (regardless of their innovative capacity) takes high risks and that their entrepreneurial activities are clearly affected by factors present in the ethnic dimension. However, in addition to the impact of ethnicity, Dana also acknowledged that the way immigrants generally recognize and pursue opportunity is influenced by a variety of factors and traits.

\section{Building A Unified Grand Relational Theory}

By asking the question 'how does ethnicity and entrepreneurship relate', scholars have identified that ethnicity (combined with a national or cultural tradition) plays a significant part in the acceleration of entrepreneurship amongst immigrant communities (Karra, 2017). For example, Peroni (2016) highlighted that first and second-generation immigrants are more likely to create new ventures than others. Also, academic research has shown that immigrant business ventures in the host countries have grown from small businesses that cater for the needs of the same ethnic and immigrant minorities to international enterprises founded on ethnic ties (Karra, 2017). However, due to the interwoven nature of the role played by an assortment of factors (i.e. differences in culture, religion, language or socioeconomic positions) towards enhancing immigrant entrepreneurial activity, the concept of ethnicity is widely viewed as a multifaceted phenomenon (Van-Sheers, 2010). From a mixed embeddedness perspective, a unified grand relational theoretical framework is required to show how immigrant entrepreneurs relate with entrepreneurship opportunity formation through ethnic influences.

While it has been argued that some immigrant business owners predominantly serve the needs of the socio-cultural or ethnic class to which they belong (Waldinger et al., 2006; Cooney and Flynn, 2008), recent studies have indicated a shift in this strategy (Bates and Robb, 2014) as immigrant entrepreneurs have gradually expanded their market area towards a much larger coverage of the urban demand (Van-Sheers, 2010). However, despite these studies, the question remains regarding what phenomenon best explains how ethnicity influences immigrant entrepreneurial activities relative to 
business opportunity formation? Arguably, the theoretical explanation for such a relationship can be analysed based upon the pattern of interactions that exists between immigrant groups, ethnic family resources and their entrepreneurial activities in the host environments. In considering the definition of 'ethnic resources' as socio-cultural features of the whole group, which co-ethnic entrepreneurs actively utilize in business or from which their business benefits, Light and Rosenstein (1995) and Yoo (2014) determined that the relationship between ethnicity and immigrant entrepreneurship could also be argued to have been impacted by ethnic resources which clearly are facilitators to the development of the immigrant entrepreneurial concept. Consequently, such a relationship has numerous faces and can be characterized by a set of connections. Thus, ethnicity and entrepreneurship share a common network within which immigrant entrepreneurs continue to grow and develop their entrepreneurial operations.

\section{FIGURE 2 ABOUT HERE}

Figure 2 suggests that ethnicity and social capital constitute a connection (meso-level) that creates porosity on immigrant ethnic boundaries to facilitate cross-group interactions between immigrant members (Pecoud, 2010). It also explains that immigrant entrepreneurs possess certain qualities (i.e. intrinsic capabilities-risk propensity, high education, unique knowledge or identity) which increases their likelihood to venture into self-employment beyond the natives of the host country (Karra, 2017). Furthermore, the figure shows that all immigrants have ethnic origins connected by either bloodties, ancestry, peoplehood, etc (Brett, 2002). This is further supported by the work of Evansluong (2016) who acknowledged that an immigrants' business venture/opportunity creation process is influenced by factors from both their home and the host countries. Hence, immigrant entrepreneurship and their business activities cannot be separated. Subject to this fact, the concept of mixed embeddedness portrays key important explanations regarding how the social, economic and institutional contexts interact with each other during the opportunity formation process amongst immigrant entrepreneurs (Kloosterman et al., 1999). A relationship describing such embeddedness with social networking activities is described as 'integration' into new cultures (Kloosterman and Rath, 2001). However, Jones et al (2014) found that while new migrants are indeed 'diverse' in many respects, the onerous nature of structural constraints limited the scope of new migrant enterprise and racism continued to cast a negative influence on the business activities of new migrants.

\section{The Mixed Embeddedness Theoretical Logic to Immigrant Entrepreneurship}

Although limited attention has been paid regarding how ethnic families influence the immigrant entrepreneurial process (Bird and Wennberg, 2016), the family remains a conduit of core cultural values for immigrant entrepreneurial start-ups (Landau, 2007). As a result, an immigrant's ethnic family business structures and relationships are more integral to their entrepreneurial management process than 
businesses founded by native entrepreneurs (Danes and Lee, 2008). For instance, Adler and Kwon's (2002) definition of social capital as goodwill that is engendered by the fabric of social relations and that can be mobilized to facilitate action, clearly differentiated the term from human capital. Thus, while social capital is embodied in relationships among people and formal social institutions, human capital is embodied in the individual. Further arguments emphasised that institutions such as places of worship and voluntary associations are major resources to immigrant entrepreneurship because they are forms of social capital to entrepreneurial business management (Tsang, 2016). Hence, as a sign of co-ethnic loyalty and ethnic institutions, they support and are supported by immigrant businesses (Aldrich and Waldinger, 1990). In Carter and Jones-Evans (2012), the concept of mixed embeddedness theory was explored from an immigrant entrepreneurial perspective. The findings revealed that in the creation of immigrant businesses, mixed embeddedness theory is a more realistic way to approach structure versus culture because firms are simultaneously grounded in social ties, the legal environment of markets and states, and in its own social capital-resources supplied by family and community. The fact that firms must act within parameters laid down by this powerful context means that an immigrant entrepreneur is indebted to social relationships.

While investigating the possible connection between immigrant entrepreneurship and the relationship between mixed embeddedness theory and business opportunity formation, research has highlighted that proponents of the mixed embeddedness construct believe that an interaction takes place between groups and the context (McKeever, 2015). This pattern of communication can easily be traced back to an immigrant entrepreneur's ethnic origins and family, and their host environment, resources and networks. Thus, immigrant entrepreneurs are influenced because they availed themselves of the supports (e.g. advice, social capital, etc) provided by these sources when setting-up business opportunities in the host countries. As Landau (2007) acknowledged, the family remains a conduit of culture and core cultural values for entrepreneurial start-ups and such influence has benefited the growth and sustenance of immigrant businesses in the host countries over the years. Given this circumstance, the Visual Mixed Embeddedness Framework (VMEF) is presented as a practical tool that best explains the central phenomenon involved during immigrant entrepreneurial opportunity formation processes.

\section{FIGURE 3 ABOUT HERE}

As a theoretical lens best used for studying and understanding immigrant entrepreneurship opportunity formation process model, the VMEF in Figure 3 further expands the theoretical logic of mixed embeddedness. Through an integration process, ideologies and perceptions are theoretically combined and visually used to explain how factors from an immigrant's home country (e.g. ethnic group characteristics, families, advice, support, etc) and traits from their host country (e.g. peers, societies, 
associations, networking, etc) combine and alter immigrants' entrepreneurial mind-sets concerning business opportunity formation as reflected in their activities and strategies. The VMEF thus encapsulates the immigrant entrepreneurship business opportunity formation process by visually explaining how the process is influenced by factors and traits from both countries. It is axiomatic that the VMEF construct simply compliments the mixed embeddedness theory as it visually represents the nature of interactions and other entrepreneurial activities that take place between immigrant entrepreneurs and the other actors within the context (i.e. social, economic, new environment, the institutional context, etc). This figure significantly differentiates between immigrant entrepreneurial business opportunity formation process models from the mainstream or native entrepreneurial approach. As a result, the VMEF could be interpreted as a practical lens that can best be used in studying the phenomenon of immigrant entrepreneurship opportunity formation process model. As such, it is equally axiomatic that families and ethnicity play a vital role in the understanding of immigrant entrepreneurship internationally and offer critical knowledge that helps in the constant development of diverse societies (De Vries, 2007). However, the presence of complexity in the action and interactions between immigrant entrepreneurs, ethnic families and the context (Johannisson, 2011; Steyaert, 2007) presented the need for additional in-depth inquiry to understand the role played by the applied orthodoxy of the VMEF during immigrant organizational formation to pursue opportunities in the host countries.

The VMEF confirms that ethnic resources are facilitators of entrepreneurial concepts and activity development amongst different immigrant groups. This acknowledgement is fundamental as it explains the nature of impact resulting from the amalgam of factors from immigrants' home countries (Turkina and Thai, 2013) and traits from the host countries (Evansluong, 2016) to immigrants' abilities to make decisions. In Kloosterman and Rath's (2001) own words, this phenomenon is described as 'integration' into new cultures. Invariably, the examined literature on immigrant entrepreneurship from the mixed embeddedness theory to opportunity formation perspectives confirmed the existence of a relationship between the actors in the context, resources and their environments. Consequently, cultural separation conditions, acculturation stress, and the 'outsidership' of actors from social and business networks affects immigrant entrepreneurship business opportunity formation processes differently (Guercini et al., 2017). Hence, they have important local and global implications on business opportunity formation (e.g. the economy, and society). To this effect, Evansluong (2016) acknowledged that both entrepreneurial and business activities indicated that immigrants' opportunity creation process is influenced by factors from both home and host countries.

\section{Conclusion}

Based on the literature reviewed, this chapter sought to demonstrate how scholars have ascertained that an immigrant's ethnic background can play an important role in the development of 
immigrant entrepreneurship in their host country. From the perspective of the mixed embeddedness theory to business opportunity formation, the question of what phenomenon best explains the nature of the relationships that exist between ethnicity and entrepreneurship has been addressed by alluding to an immigrant's ethnic ties, family and financial supports as factors connecting them. By examining ethnicity and entrepreneurship using a three-dimensional framework, an important relationship has been shown to exist between ethnicity and immigrant entrepreneurs based on the important characteristics and common features that they share. Therefore, ethnicity provides immigrant entrepreneurs with valuable resource and ideological support for mercantile association when faced with restraint of trade caused by environmental factors. Similarly, the interactions between immigrant entrepreneurs, resources and their environments is axiomatic relative to an immigrant business and an opportunity development model, and that entrepreneurial success cannot be traced back to a single characteristic but to the complex interactions between opportunity structure, immigrant ethnic families and group resources. Hence, ethnicity can bring immigrant entrepreneurs together around an ideology of solidarity and offer a countervailing force that protects them against market competition.

Based on scholarly recognition that immigrant entrepreneurship is successful because of the mobilization of family forces, the important role played by ethnicity in the development of immigrant entrepreneurship is widely acknowledged. Thus, in considering the interwoven nature of the role played by different factors, the nature of the relationship between ethnicity and entrepreneurship is recognised as being multifaceted. Therefore, these factors equally define the connection between ethnicity and immigrant entrepreneurs because they comprise basic characteristics and features found in the mixed embeddedness theoretical logic through mutual compliments. While entrepreneurship benefits from social networks created by ethnic groups, immigrant entrepreneurs serve as negotiators for large firms to attract cheap labor which ultimately reduces their production costs. Therefore, in the development of immigrant entrepreneurial ventures, ethnic ties play a crucial role through sharing common cultural norms that facilitate both concepts to function and operate in unison. In retrospect, ethnic families remain a conduit of culture and core cultural values for entrepreneurial start-ups.

The chapter has developed and introduced the Visual Mixed Embeddedness Framework (VMEF) to illustrate how immigrant entrepreneurs view business opportunity formation differently in comparison to native entrepreneurs. By explaining how factors and traits from both countries impact upon the immigrant entrepreneurial business activity process, the framework clearly identified how the concept of ethnicity influences immigrant entrepreneurial opportunity formation activities in different ways. In addition, the framework demonstrates how immigrant businesses are shaped by their ethnic origins, regional group's characteristics, etc. Thus, ethnicity influences immigrant businesses through ethnic ties and connections with member groups. As a result, immigrant entrepreneurs single-handedly influence the nature, form and pattern of entrepreneurial opportunity formation process by leaving traditional paid jobs to create business opportunities of their own. Thus, they reduce job creation 
demands on host governments by contributing to business opportunity formation and the development of their host economies. By explaining how factors and traits from both home and host countries impact upon the immigrant entrepreneurial business activity process, the framework clearly identifies how the concept of ethnicity influences immigrant entrepreneurial opportunity formation activities in different ways. The framework contributes to existing knowledge by offering a novel method for examining the influence on business opportunity formation of ethnicity, the role of home and host countries, and variations between immigrant and native entrepreneurs.

\section{References}

Ado, A., Chrysostome, E., \& Su, Z. (2016). Examining Adaptation Strategies of Sub-Saharan African Immigrant Entrepreneurs in China: The Case of Guangdong. Journal of Developmental Entrepreneurship, 21(04).

Adler, P. S., \& Kwon, S. W. (2002). Social capital: Prospects for a new concept. Academy of management review, 27(1), 17-40.

Aldrich, H. E., \& Waldinger, R. (1990). Ethnicity and entrepreneurship. Annual review of sociology, 16(1), 111-135.

Alexandre-Leclair, L. (2014). Diversity as a motive for entrepreneurship? The case of gender, culture and ethnicity. Journal of Innovation Economics \& Management, 14(2), 157-175.

Alvarez, S. A., \& Barney, J. B. (2007). Discovery and creation: Alternative theories of entrepreneurial action. Strategic entrepreneurship journal, 1(1-2), 11-26.

Bates, T., \& Robb, A. (2014). Small-business viability in America's urban minority communities. Urban Studies, 51(13).

Bird, M., \& Wennberg, K. (2016). Why family matters: The impact of family resources on immigrant entrepreneurs' exit from entrepreneurship. Journal of Business Venturing, 31(6), 687-704.

Blanding, M (2016). One Quarter of Entrepreneurs in The United States Are Immigrants. Forbes Magazine, Aug 31, 2016

Boissevain, J., Blaschke, J., Grotenbreg, H., Joseph, I., Light, I., Sway, M., Waldinger, R \& Werbner, P. (1990). Ethnic entrepreneurs and ethnic strategies. Ethnic entrepreneurs: Immigrant business in industrial societies, 131-156.

Brett, M. G. (Ed.). (2002). Ethnicity and the Bible. Brill Academic Publishers, Inc. Leiden.

Burn-Callendar, R. (2016). Immigrants far more likely to be entrepreneurial than British born. The Telegraph, 12 May 2016.

Bygrave, W. D. (1997). The entrepreneurial process. The Portable MBA in Entrepreneurship, 4th Edition, 1-26.

Bergson, A. (1983). Pareto on social welfare. Journal of Economic Literature, 21(1), 40-46.

Carter, S. and Jones-Evans, D. (2012). Enterprise and small business: Principles, practice and policy. Strategic Direction, 25(5).

Cooney, T. M., \& Flynn, A. (2008). A mapping of ethnic entrepreneurship in Ireland. Dublin Institute of Technology, Dublin. 
Cooney, T. M., \& Murray, T. M. (2008). Entrepreneurship education in the third-level sector in Ireland. Reports, 2.

Dana, L. P. (Ed.). (2007). Handbook of research on ethnic minority entrepreneurship: A co-evolutionary view on resource management. Edward Elgar Publishing.

Danes, S. M., Lee, J., Stafford, K., \& Heck, R. K. Z. (2008). The effects of ethnicity, families and culture on entrepreneurial experience: An extension of sustainable family business theory. Journal of Developmental Entrepreneurship, 13(03), 229-268.

Davidsson, P. (2003). The domain of entrepreneurship research: Some suggestions. In Cognitive approaches to entrepreneurship research (pp. 315-372). Emerald Group Publishing Limited.

De Vries, H. P. (2007). The influence of migration, settlement, cultural and business factors on immigrant entrepreneurship in New Zealand.

Dimov, D. (2007a). Beyond the single-person, single-insight attribution in understanding entrepreneurial opportunities. Entrepreneurship Theory and Practice, 31(5), 713-731.

Evansluong, Q. V. (2016). Opportunity creation as a mixed embedding process: A study of immigrant entrepreneurs in Sweden (Doctoral dissertation, Jönköping University, Jönköping International Business School).

Guercini, S., Dei Ottati, G., Baldassar, L., \& Johanson, G. (Eds.). (2017). Native and immigrant entrepreneurship: Lessons for local liabilities in globalization from the Prato Case Study. Springer.

Johannisson, B. (2011). Towards a practice theory of entrepreneuring. Small Business Economics, $36(2), 135-150$.

Jones, T., Ram, M., Edwards, P., Kiselinchev, A., \& Muchenje, L. (2014). Mixed embeddedness and new migrant enterprise in the UK. Entrepreneurship \& Regional Development, 26(5-6), 500-520.

Karra, N. (2017). Understanding the Born Global Firm. Taylor \& Francis.

Kloosterman, R., \& Rath, J. (2001). Immigrant entrepreneurs in advanced economies: mixed embeddedness further explored. Journal of ethnic and migration studies, 27(2), 189-201.

Kloosterman, R., Van Der Leun, J., \& Rath, J. (1999). Mixed embeddedness:(in) formal economic activities and immigrant businesses in the Netherlands. International journal of urban and regional research, 23(2), 252-266.

Kusow, A. M., Ajrouch, K. J., \& Corra, M. (2018). Socioeconomic Achievement Among Arab Immigrants in the USA: The Influence of Region of Origin and Gender. Journal of International Migration and Integration, 19(1), 111-127.

Lassalle, P. and McElwee, G. (2016). Polish entrepreneurs in Glasgow and entrepreneurial opportunity structure. International Journal of Entrepreneurial Behavior \& Research, Vol. 22 Issue: 2, pp.260281.

Landau, J. (2007). Enhancing resilience: Families and communities as agents for change. Family process, 46(3), 351-365.

Light, I. (1984). Immigrant and ethnic enterprise in North America. Ethnic and racial studies, 7(2), 195216.

Lieberson, S. (1980). A piece of the pie: Blacks and white immigrants since 1880. Univ of California Press.

Light, I. H., \& Rosenstein, C. N. (1995). Race, ethnicity, and entrepreneurship in urban America. Transaction Publishers. 
McKeever, E., Jack, S., \& Anderson, A. (2015). Embedded entrepreneurship in the creative reconstruction of place. Journal of Business Venturing, 30(1), 50-65.

Moroz, P. W., \& Hindle, K. (2012). Entrepreneurship as a process: Toward harmonizing multiple perspectives. Entrepreneurship Theory and Practice, 36(4), 781-818.

OECD (2011). Migrant Entrepreneurship in OECD Countries (Part II). OECD, Paris.

Ong, P. (1981). An ethnic trade: The Chinese laundries in early California. The Journal of Ethnic Studies, 8(4), 95.

Pécoud, A. (2010). What is ethnic in an ethnic economy? International Review of Sociology, 20(1), 5976.

Peroni, C., Riillo, C. A., \& Sarracino, F. (2016). Entrepreneurship and immigration: evidence from GEM Luxembourg. Small Business Economics, 46(4), 639-656.

Peterson, W. (1980). Concepts of Ethnicity. As cited in Waldinger, R. D., Aldrich, H., \& Ward, R. (1990). Ethnic entrepreneurs: Immigrant business in industrial societies (Vol. 1). Sage Publications, Inc.

Prashantham, S., Dhanaraj, C., \& Kumar, K. (2015). Ties that bind: Ethnic ties and new venture internationalization. Long Range Planning, 48(5), 317-333.

Rahman, M.Z.; Ullah, F. and Thompson, P. (2018). Challenges and issues facing ethnic minority small business owners: The Scottish experience. International Journal of Entrepreneurship and Innovation, First Published January 23, 2018

Ram, M., Jones, T., \& Villares-Varela, M. (2016, 2017). Migrant entrepreneurship: Reflections on research and practice. International Small Business Journal, 35(1), 3-18.

Steyaert, C. (2007). 'Entrepreneuring' as a conceptual attractor? A review of process theories in 20 years of entrepreneurship studies. Entrepreneurship and regional development, 19(6), 453-477.

Van Scheers, L. (2010). The role of ethnicity and culture in developing entrepreneurs in South Africa. Problems and perspectives in Management, 8(4), 20-28.

Tsang, W. Y. (2016). Integration of Immigrants: The role of ethnic churches. Journal of International Migration and Integration, 16(4), 1177-1193.

Turkina, E., \& Thi Thanh Thai, M. (2013). Social capital, networks, trust and immigrant entrepreneurship: A cross-country analysis. Journal of Enterprising Communities: People and Places in the Global Economy, 7(2), 108-124.

Valdez, Z (2016). Intersectionality, the household economy, and ethnic entrepreneurship. Ethnic and Racial Studies, 39:9, 1618-1636

Waldinger, R. (2006). Immigrant" Transnationalism" and the Presence of the Past. Revue européenne des migrations internationales, 22(2), 23.

Waldinger, R. D., Aldrich, H., \& Ward, R. (1990). Ethnic entrepreneurs: Immigrant business in industrial societies (Vol. 1). Sage Publications, Inc.

Waldinger, R., Aldrich, H., Ward, R., \& Blaschke, J. (1990). Immigrant Entrepreneurs: Immigrant Business in Industrial Societies.

Yeasmin, N. (2016). The determinants of sustainable entrepreneurship of immigrants in Lapland: An analysis of theoretical factors. Entrepreneurial Business and Economics Review, 4(1), 129.

Yoo, J. K. (2014). Korean Immigrant Entrepreneurs: Networks and Ethnic Resources. Routledge. 
Zhou M. and Liu H. (2017). Immigrant Entrepreneurship and Diasporic Development: The Case of New Chinese Migrants in the USA. In: Zhou M. (eds) Contemporary Chinese Diasporas. Palgrave, Singapore. 
Figure 1: Enhanced Interactive Model on Factors Influencing Immigrant Entrepreneurship

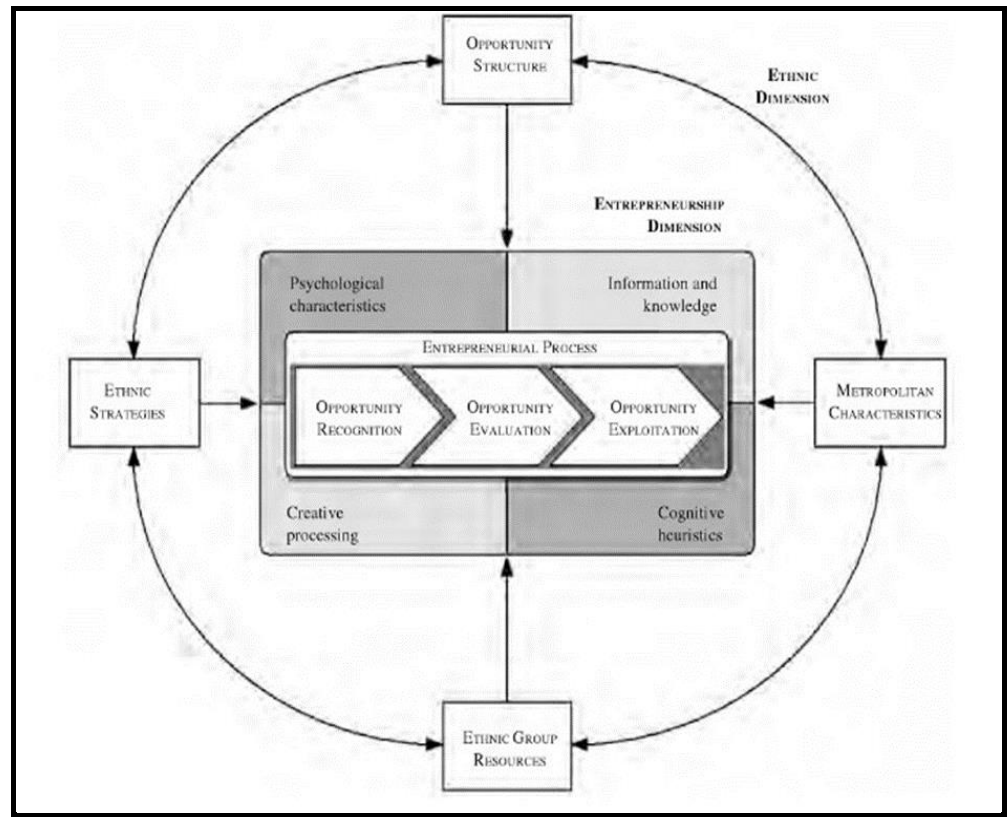

Source: Volery, 2007, Figure 3.2, p.36

Figure 2: A Unified Grand Relational Theory

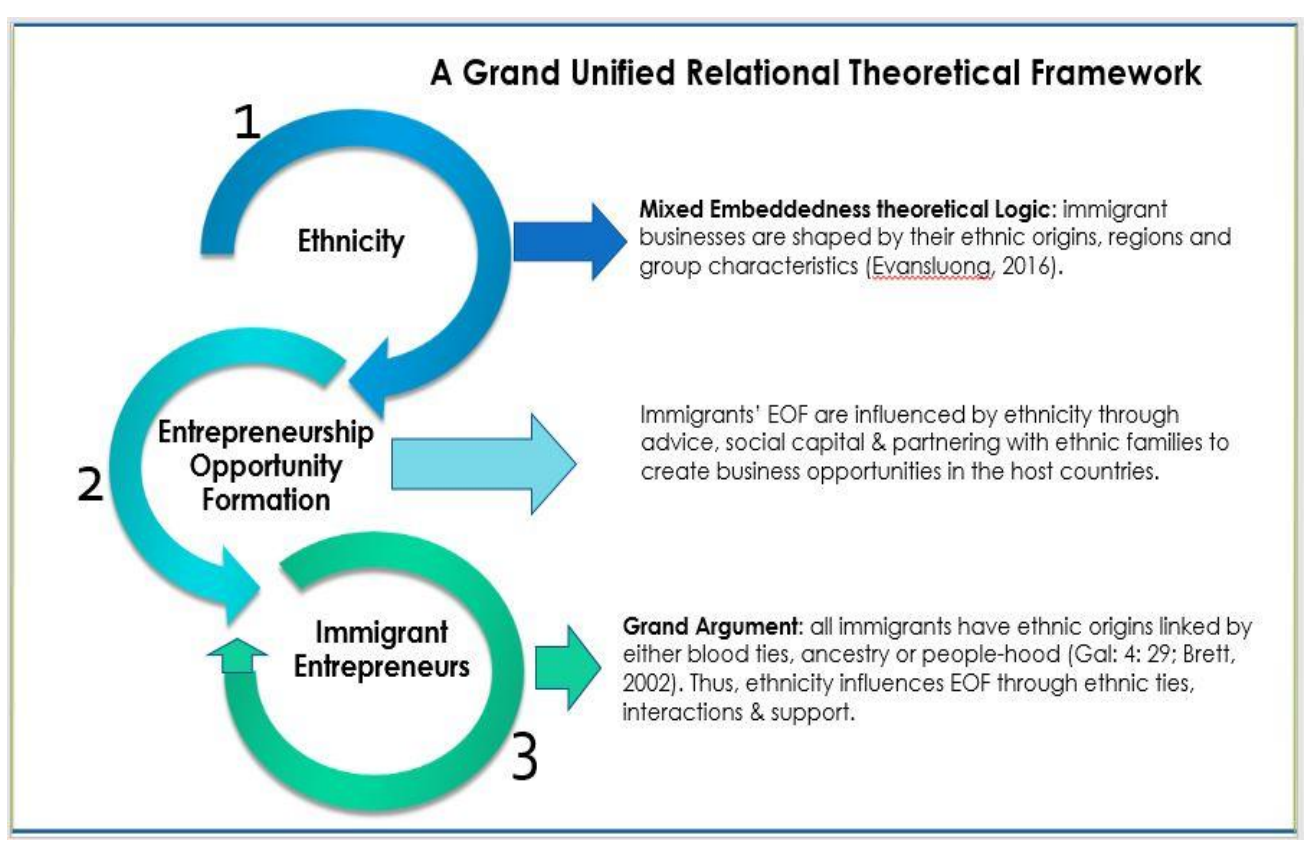

Source: Authors 
Figure 3: The VMEF and Immigrant Entrepreneurship Opportunity Formation Process

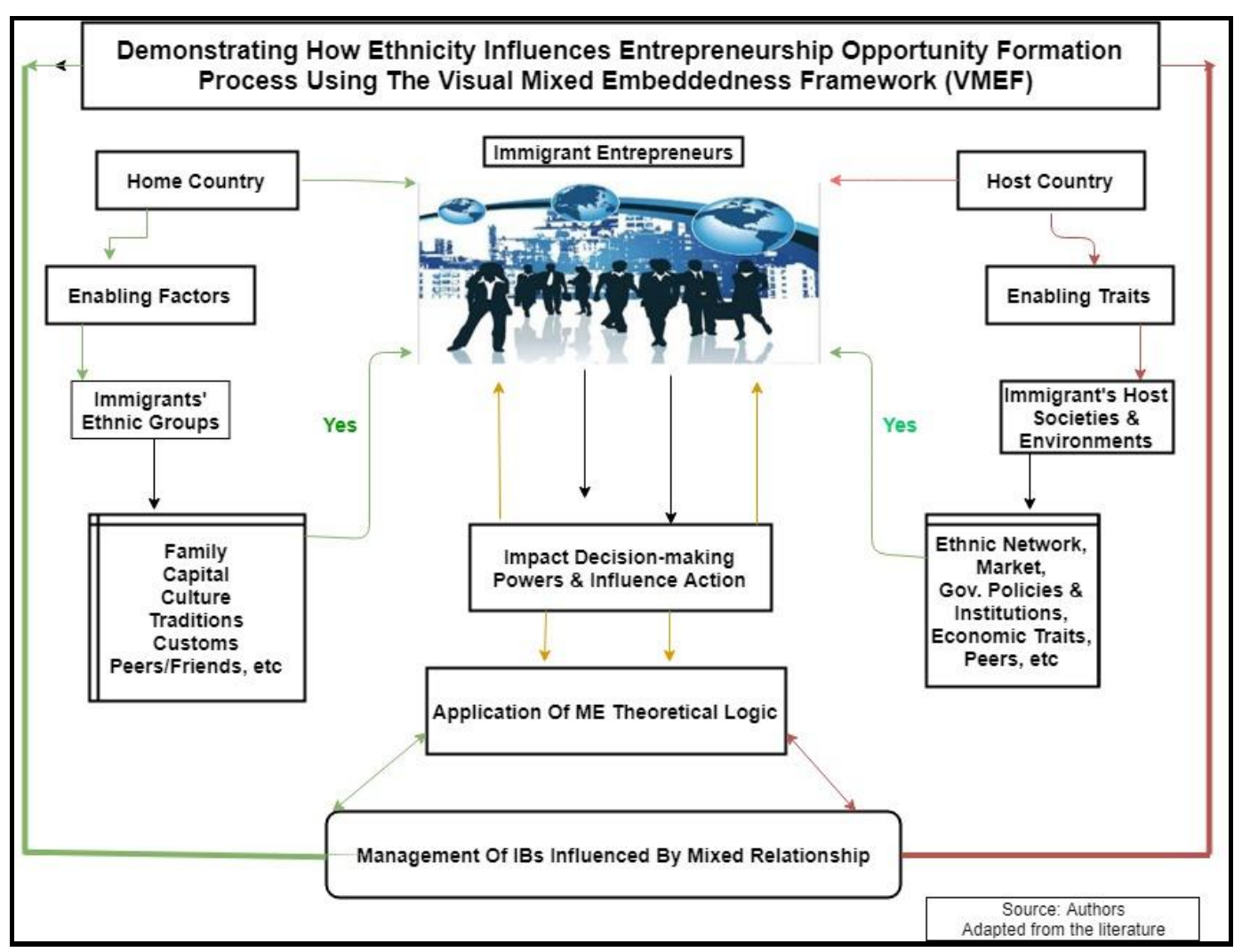

